\title{
Наукометричний аналіз публікаційної активності науковців ДУ «Інститут ендокринології та обміну речовин ім. В.П. Комісаренка НАМН України» за даними наукометричної бази даних Google Scholar
}

М.Д. Тронько, І.П. Пастер

ДУ «Інститут ендокринології та обміну речовин ім. В.П. Комісаренка НАМН України»

\begin{abstract}
Резюме. Мета дослідження - наукометричний аналіз публікаційної активності науковців ДУ «Інститут ендокринології та обміну речовин ім. В.П. Комісаренка НАМН України» (далі — Інститут) за даними наукометричної бази даних Google Scholar. Матеріали та методи. Метод дослідження - наукометричний аналіз наукових публікацій за даними наукометричної бази даних Google Scholar. Oб'єктом дослідження стали всі бібліометричні профілі науковців Інституту на платформі Google Scholar, а предметом дослідження - кількість бібліографічних посилань на всі публікації, h-індекс та i10-індекс за весь період і 2013 року. Результати. Особисті бібліометричні профілі створили 27 науковців. Кількість бібліографічних посилань у 3 науковців становить 6484, 4234 і 1304 одиниці, у 4 - від 501 до 1000, у 7 - від 101 до 500 і в 13 науковців - до 100. Один науковець має індекс Гірша 43, 1 - 34, 3 - від 11 до 20, 5 - від 6 до 10 і 17 - від 1 до 5. У 19 науковців є публікації, які мають принаймні 10 бібліографічних посилань. Висновок. Останніми декількома роками рівень цитування публікацій науковців залишається стабільним.
\end{abstract}

Ключові слова: ДУ «Інститут ендокринології та обміну речовин ім. В.П. Комісаренка НАМН України», публікації науковців, наукометрична база даних Google Scholar, наукометричний аналіз.

* Адреса для листування (Correspondence): ДУ «Інститут ендокринології та обміну речовин ім. В.П. Комісаренка НАМН України», вул. Вишгородська, 69, м. Київ, 04114,

Україна. E-mail: pasteur@ukr.net

○ М.Д. Тронько, І.П. Пастер 
На сьогодні Державна установа «нсститут ендокринології та обміну речовин ім. В.П. Комісаренка НАМН України» (далі - Інститут) $€$ науковим, консультативним і лікувальним закладом, що надає допомогу дорослим і дітям із захворюваннями щитоподібної залози, цукровим діабетом та іншою ендокринною патологією.

Також Інститут є провідною в Україні науково-дослідною базою для підготовки аспірантів, клінічних ординаторів, захисту докторських і кандидатських дисертацій за фахом «ендокринологія», підготовки фахівців на курсах стажування та інформації.

Інститут виконує широке коло фундаментальних і прикладних науково-дослідних робіт, результати яких високо цінуються науковими співробітниками і практикуючими лікарями.

Водночас актуальною залишається проблема оцінки наукового добутку кожного співробітника Інституту [1]. Для цього використовують наукометричні показники, які розраховують за допомогою наукометричних баз даних. Кожна така база - це бібліографічна та реферативна база даних з інструментами для відстеження цитованості статей, опублікованих у наукових виданнях, із можливістю індексування посилань, зазначених у пристатейних списках цих публікацій, і розрахунку кількісних показників цих посилань. Завдяки таким базам можна оцінити продуктивність праці вченого та його вплив на світову науку, що опосередковано може свідчити про якість наукових досліджень.

Найвідомішими наукометричними базами є Web of Science, SciVerse Scopus i Google Scholar.

Web of Science є базисом глобального електронного науково-інформаційного середовища Інституту наукової інформації (Information Sciences Institute) США, що сьогодні входить до складу корпорації Thomson Reuters [2]. Бази даних Інституту наукової інформації створювалися насамперед як пошукові, оскільки вони дають змогу проводити багатоаспектний пошук наукової літератури. Статистичні дані, що містяться в цих базах, за своїм обсягом перевершують усі наявні дані подібного роду. На їх підставі стало можливим введення та використання важливих кількісних характеристик розвитку науки.

Загалом Web of Science обробляє до 12 тисяч назв найбільш авторитетних академічних журналів, а також збірників наукових праць і мате- ріалів конференцій [2]. Наукометричний апарат платформи забезпечує відстеження показників цитованості публікацій у медико-біологічних науках із ретроспективою до 1900 року.

Отже, наразі Web of Science є системою баз даних, що містять бібліографічні описи всіх статей з оброблюваних наукових журналів, а також бібліографічні посилання на інші праці, зазначені в певній статті, та інформацію про всі статті, що посилаються на певну роботу [2].

SciVerse Scopus є складовою частиною інтегрованого науково-інформаційного середовища SciVerse - це реферативна та наукометрична база даних, створена 2004 року видавничою корпорацією Elsevier як продукт-конкурент Web of Science [2]. Оскільки SciVerse Scopus з'явився як результат механічного злиття та часткового доповнення існуючих реферативних баз даних Elsevier, його початковий індекс було сформовано $з$ тих видань, які станом на 2004 рік індексувалися провідними галузевими реферативними базами даних (Inspec, Compendex, Medline, GeoBase тощо).

Станом на липень 2013 року SciVerse Scopus містила понад 49,3 млн реферативних записів [2]. У тому числі в базі даних проіндексовано 20 тис. назв наукових журналів 5 тис. видавництв, 340 книжкових серій і 5,3 млн праць конференцій. Наукометричний апарат SciVerse Scopus забезпечує отримання показників цитованості наукових праць у виданнях, опублікованих після 1996 року.

Наукометричним показником, прийнятим y SciVerse Scopus, є h-індекс (індекс Хірша) [2, 3]. Цей показник запропонував 2005 року американський фізик Х. Хірш для оцінки результативності наукової діяльності вчених як альтернативу імпакт-фактору - традиційному наукометричному показнику. У підрахунку індексу Хірша враховуються дві кількісні характеристики: кількість публікацій ученого та кількість цитат на праці вченого. Істотною відмінністю індексу Хірша від імпакт-фактора є врахування всіх цитат на працю, незалежно від давності публікації (у підрахунку імпакт-фактора враховується лише цитованість праці протягом двох років після її публікації).

Механізм розрахунку індексу Хірша такий: учений має індекс $\mathrm{h}$, якщо $\mathrm{h}$ із його $\mathrm{Np}$ робіт мають кількість цитувань більшу або рівну $\mathrm{h}$ кожна, а інші роботи $(\mathrm{Np}-\mathrm{h})$ мають кількість 
цитувань меншу, ніж h, кожна [2, 3]. Тобто, учений з індексом h має h (або більше) публікацій, кожну з яких процитовано h (або більше) разів. Отже, якщо перелік праць ученого оформити у вигляді списку, ранжованого за цитованістю (від найбільш до найменш цитованих), індекс h буде обмежений останньою в списку працею, порядковий номер якої в списку є меншим, ніж кількість їі цитувань, або дорівнює кількості цитувань. Індекс Хірша є кількісною характеристикою продуктивності вченого за весь період наукової діяльності. Як і будь-який формальний показник, індекс h має свої переваги та недоліки.

Світові лідери, які створюють такі бази даних, - корпорації Thomson Reuters i Elsevier надають необхідний сервіс лише на комерційних засадах, і доступний він обмеженому колу вітчизняних дослідників [2]. Тому вбачається доцільним використання показників некомерційних наукометричних платформ та інструментаріїв паралельно з показниками комерційних баз даних.

Серед вільнодоступних систем наукометричного спрямування насамперед слід відзначити Google Scholar корпорації Google, що сьогодні є лідером пошукових систем Інтернету [2, 4]. Наразі Google щоденно реєструє близько 50 млн пошукових запитів та індексує понад 8 млрд веб-сторінок. Google може знаходити інформацію понад 100 мовами, має найбільшу базу проіндексованих документів і декілька варіантів пошуку.

Google Scholar є науковим сегментом Інтернет-гіганта Google, що поєднує загальнодоступну пошукову та бібліометричну систему [2]. Ця система подібна до Web of Science i SciVerse Scopus, хоча поступається їм за функціональними можливостями. Google Scholar дає можливість користувачам здійснювати пошук публікацій із посиланнями на повнотекстові статті, технічні звіти, препринти, дисертації, книги та інші документи, що вважаються науковими, проте починаючи лише з 1990 року.

Оскільки значна частина результатів пошуку містить посилання на комерційні журнальні статті, користувачі можуть отримати доступ лише до анотацій статей [2]. Крім цього, система індексує і документи, які не пройшли належної експертної оцінки [5].

Результати пошуку впорядковуються насамперед за кількістю цитувань публікації [2].
Google Scholar забезпечує користувачів як даними про індекс цитування документа, раніше доступний лише в комерційних наукометричних платформах, так і списками семантично споріднених матеріалів. За обсягами проіндексованих матеріалів система Google Scholar перевищує Web of Science i SciVerse Scopus.

Для зручного відстежування бібліографічних посилань на свої статті Google Scholar пропонує науковцям створити свій власний профіль у системі [5]. Профіль дозволяє науковцю оперативно дізнаватися, хто цитує його публікації, переглядати графіки цитувань у часі та автоматично розраховувати деякі наукометричні показники.

Загальнодоступність і глибина охоплення проіндексованої наукової інформації привернули до Google Scholar увагу значної кількості дослідників, які розробили спеціалізовані інструментарії для розширення наукометричних функціональних можливостей цієї системи [2]. Одним із них є безкоштовна програма-агрегатор Publish or Perish, яка використовує інформаційні ресурси Google Scholar як первинну базу для визначення та наочного представлення вибраних для аналізу бібліометричних даних [6]. За iï допомогою можна здійснювати аналіз публікаційної активності науковців і вагомості періодичних видань. У разі дослідження вагомості періодичного видання ця програма надає інформацію про загальну кількість проіндексованих статей, загальну кількість посилань на них, середню кількість посилань на статтю, загальну та середню кількість праць і цитувань за певний період, h-індекс журналу (h - кількість статей, на які є щонайменше h посилань) тощо.

Системою Google Scholar охоплено практично всі українські наукові часописи, представлені в мережі Інтернет (1,8 тис.) [2]. Як уже зазначалося раніше, корпорації Elsevier i Thomson Reuters проіндексували лише по 18 із них. Також за допомогою цього інструментарію здійснено аналіз публікаційної активності вчених України. Оцінку рейтингу вчених проведено за h-індексом (h - кількість статей науковця, на які є посилання в понад h публікаціях), а в межах одного індексу - за кількістю цитувань. В аналізі враховано прізвища та ініціали вченого українською, російською та англійською мовами.

Показано кореляцію бібліометричних показників учених у системі Google Scholar, яка є безкоштовною, з аналогічними показниками в ко- 
мерційних платформах SciVerse Scopus i Web of Science [2]. Водночас слід наголосити, що Google Scholar має значнішу джерельну базу та істотніше географічне, галузеве та мовне покриття.

Важливо усвідомлювати, що будь-яка бібліометрична база - це механічна система, що опрацьовує інформацію зі списків бібліографічних посилань, порівнюючи нові надходження з уже наявними в системі [2]. Оскільки порівняння здійснюються автоматично, бібліографічні списки можуть працювати на наукометричні показники науковців або установ лише тоді, коли вони придатні до машинного розбору [7].

Фахівці відділу бібліометрії та наукометрії служби інформаційно-аналітичного забезпечення Національної бібліотеки України ім. В.I. Вернадського розробили систему «Бібліометрика української науки», призначену для надання суспільству цілісного уявлення про вітчизняне наукове середовище; ця сиситема є національною складовою проекту Ranking of Google Scholar Profiles [8, 9].

Ця система - це аналітична інформація про галузеву, відомчу та регіональну структуру науки України, єдиний реєстр наукових декларацій (бібліометричних профілів) учених і дослідницьких колективів, а також джерельна база для експертного оцінювання результативності наукової діяльності $[8,9]$. Інформаційні ресурси системи формуються шляхом опрацювання бібліометричних профілів, створених науковцями на платформі Google Scholar і бібліометричних показників комерційних систем Scopus i Web of Science. Оновлення значень індексів Гірша від Google Scholar здійснюється щомісячно.

Мета дослідження - наукометричний аналіз публікаційної активності науковців ДУ «Інститут ендокринології та обміну речовин ім. В.П. Комісаренка НАМН України» за даними наукометричної бази даних Google Scholar.

\section{Матеріали та методи}

Метод дослідження - наукометричний аналіз наукових публікацій за даними наукометричної бази даних Google Scholar.

Об'єктом дослідження стали всі бібліометричні профілі науковців Інституту на платформі Google Scholar, а предметом дослідження кількість бібліографічних посилань на всі публікації, h-індекс (найбільше значення h, за якого h публікацій мають принаймні h бібліографічних посилань) та i10-індекс (кількість публікацій, які мають принаймні 10 бібліографічних посилань) за весь період і з 2013 року.

\section{Результати та їх обговорення}

На пошуковий запит система «Бібліометрика української науки» Національної бібліотеки України ім. В.I. Вернадського видає інформацію про бібліометричні профілі, створені 13 науковцями Інституту на платформі Google Scholar (дані оновлено 08.10.2018 року) [10]. Ще 14 записів знайдено в результаті ручного пошуку безпосередньо в базі Google Scholar.

Отже, 27 науковців створили свої бібліометричні профілі на платформі Google Scholar (таблиця). Кількість бібліографічних посилань у 2 науковців становить 6484 і 4234 одиниці, що в декілька разів перевищує відповідний показник інших співробітників Інституту: в 1 науковця $(3,7 \%$ від загальної кількості) - 1304 одиниці, у 4 науковців (14,8\%) - від 501 до 1000, у 7 науковців (25,9\%) - від 101 до 500 і в 13 науковців (48,2\%) - до 100 .

Аналіз динаміки бібліографічних посилань за останні 7 повних років (2011-2017 роки) показав позитивну динаміку в більшості науковців: у 4 науковців - суттєве зростання, у 2 науковців - значне зростання, у 4 науковців - зростання і в 10 науковців показник залишався майже без змін [4]. На жаль, у 7 науковців визначено дещо негативну динаміку.

Один науковець (3,7\% від загальної кількості) має індекс Гірша 43, 1 (3,7\%) - 34, 3 (11,1\%)від 11 до 20, 5 (18,5\%) - від 6 до 10 і 17 науковців (63,0\%) - від 1 до 5 (таблиця).

У 19 науковців Інституту (70,3\% від загальної кількості) є публікації, які мають принаймні 10 бібліографічних посилань: у 2 науковців цей показник становить 111 і 63, у 3 - від 11 до 20, у 5 - від 6 до 10, у 9 - від 1 до 5 (таблиця).

Відомо, що наукометрична база даних - це бібліографічна та реферативна база даних з інструментами для відстеження цитованості статей, опублікованих у наукових виданнях [11]. Проте наявність статті в одній із міжнародних баз ще не є підтвердженням її якості, важливими є ті кількісні показники, які цими системами розраховуються для кожної статті/автора/організації. 
Оригінальні дослідження

Таблиця. Розподіл науковців Інституту за даними Google Scholar

\begin{tabular}{|c|c|c|c|c|}
\hline $\begin{array}{l}\text { № } \\
3 / \Pi\end{array}$ & ПІБ & $\begin{array}{l}\text { Бібліогра- } \\
\text { фічні по- } \\
\text { силання }\end{array}$ & h-індекс & $\begin{array}{l}\text { i10- } \\
\text { індекс }\end{array}$ \\
\hline 1 & Тронько М.Д. * & $6484 / 2753$ & $43 / 29$ & $111 / 66$ \\
\hline 2 & Богданова Т.І. * & 4234 / 1870 & $34 / 27$ & $63 / 45$ \\
\hline 3 & Резніков О.Г. * & 699 / 177 & $15 / 7$ & $20 / 5$ \\
\hline 4 & Кравченко В.І. * & $790 / 371$ & $12 / 10$ & $14 / 10$ \\
\hline 5 & Халангот М.Д. & $1304 / 875$ & $11 / 10$ & $13 / 10$ \\
\hline 6 & Корпачев В.В. & $372 / 190$ & $9 / 6$ & $9 / 3$ \\
\hline 7 & Коваленко А.Є. & $527 / 209$ & $9 / 5$ & $8 / 3$ \\
\hline 8 & Зурнаджи Л.Ю. * & $442 / 368$ & $8 / 8$ & $8 / 8$ \\
\hline 9 & Пушкарьов В.М. * & $233 / 123$ & $8 / 6$ & $7 / 3$ \\
\hline 10 & Кваченюк А.М. * & $602 / 239$ & $8 / 5$ & $7 / 4$ \\
\hline 11 & Попова В.В. & $116 / 51$ & $7 / 4$ & $4 / 1$ \\
\hline 12 & Орленко В.Л. & $188 / 93$ & $6 / 5$ & $5 / 2$ \\
\hline 13 & Ковзун О.І. * & $121 / 90$ & $5 / 5$ & $3 / 1$ \\
\hline 14 & Корпачова-Зінич О.В. * & $87 / 71$ & $5 / 5$ & $1 / 1$ \\
\hline 15 & Болгарська С.В & $98 / 59$ & $5 / 4$ & $2 / 2$ \\
\hline 16 & Лучицький Є.В. & $120 / 52$ & $5 / 3$ & $1 / 1$ \\
\hline 17 & Пастер І.П. * & $48 / 33$ & $4 / 3$ & $1 / 0$ \\
\hline 18 & Самсон О.Я. & $37 / 25$ & $4 / 3$ & $1 / 0$ \\
\hline 19 & Лучицький В.Є. & $22 / 14$ & $3 / 2$ & $0 / 0$ \\
\hline 20 & Божок Ю.М. & $15 / 3$ & $3 / 1$ & $0 / 0$ \\
\hline 21 & Таращенко Ю.М. & $15 / 12$ & $2 / 2$ & $0 / 0$ \\
\hline 22 & Соколова Л.К. & $9 / 8$ & $2 / 2$ & $0 / 0$ \\
\hline 23 & Прибила О.В. * & $6 / 6$ & $2 / 2$ & $0 / 0$ \\
\hline 24 & Тронько К.М. & $16 / 10$ & $1 / 1$ & $1 / 0$ \\
\hline 25 & Левчук Н.І. * & $9 / 8$ & $1 / 1$ & $0 / 0$ \\
\hline 26 & Спринчук Н.А. & $5 / 5$ & $1 / 1$ & $0 / 0$ \\
\hline 27 & Вишневська О.А. * & $5 / 4$ & $1 / 1$ & $0 / 0$ \\
\hline
\end{tabular}

Примітка: список співробітників впорядковано згідно з $h$-індексом та і10-індексом за весь період / з 2013 року; * - співробітники згідно з пошуковим запитом системи «Бібліометрика української науки» Начіональної бібліотеки України ім. В.І. Вернадського [10]; «Бібліографічні посилання» — кількість бібліографічних посилань на всі публікачії; « коли $h$ публікачій мають принаймні $h$ бібліографічних посилань; «і10-індекс» - кількість публікачій, які мають принаймні 10 бібліографічних посилань.

На жаль, наразі широко застосовується оцінка наукового доробку співробітника, колективу або організації за кількістю опублікованих статей, монографій, підручників, отриманих патентів тощо [12]. Тому і наукова діяльність 3водиться до написання якомога більшої кількості рукописів, часто низької якості, що надто легко зробити за умов формального рецензування редакціями спеціалізованих видань.

Також керівництвом багатьох вітчизняних університетів впроваджено додаткові фінансові заохочення для авторів публікацій із метою стимулювання росту наукової продуктивності та відображення ii результатів у наукометричних ресурсах [13]. Так, має місце практика преміювання науковців за публікації в закордонних періодичних виданнях, які індексуються базами даних Web of Science, Scopus (Київський університет імені Бориса Грінченка), за публікації у виданнях з імпакт-фактором понад 1 (Харківський національний університет імені В.Н. Каразіна), відповідно до рівня видання за імпакт-фактором (Сумський державний університет) і відповідно до імпакт-фактора журналу та наукометричної бази даних Scopus (Чернівецький національний університет імені Юрія Федьковича) [14].

Також для участі в різного роду конкурсних відборах (на вакантну посаду, проектів наукових досліджень тощо) серед іншого для кожного виконавця необхідно вказати кількість статей у виданнях, що індексуються в наукометричних базах даних, що свідчить про спробу залучення наукометричних методів у процеси конкурсного відбору [12].

Як приклад, відповідно до наказу ректора Національного технічного університету України «Київський політехнічний інститут імені Ігоря Сікорского» усі наукові та науково-педагогічні працівники університету мали зареєструватися та забезпечити актуалізацію авторських профілів у службі Google Academia (Google Scholar) відповідно до інструкції як додатку до наказу [15].

Інтерпретація наукометричних показників: кількість статей - показник наукової продуктивності, сумарна кількість цитувань та їх зіставлення в межах однієї предметної галузі показник наукового авторитету або впливовості; нормалізована середня цитованість - показник наукової ефективності [5].

Згідно з наявними в Google Scholar бібліометричними портретами, Інститут у рейтингу відомств та установ України за кількістю науковців, індекс Гірша яких $\geq 20$, посідав 46-80-у позицію (2 науковці), $\geq 30-14-22-у$ позицію (2 науковці) i $\geq 40-5-25-y$ позицію (1 науковець) (дані станом на 31.03.2018 року) [16-18]. На жаль, останнім часом інформацію із цього питання обмежено «Топ-10 установ».

Із технічних причин (відсутність бібліометричного профілю) Інститут відсутній у рейтингу установ і в рейтингу наукових колективів (дані оновлено відповідно 08.10.2018 року і 01.08.2018 року) $[19,20]$. 
Водночас потрібно пам'ятати, що наукометричні дані є лише допоміжними індикаторами в оцінці наукового доробку, а перше правило знаменитого Лейденського маніфесту, який пропонує десять принципів коректного використання наукометрії, вчить, що не можна підміняти експертну оцінку кількісною [13, 21].

Так, 16 грудня 2012 року на щорічній конференції Американського товариства клітинної біології (American Society for Cell Biology) у СанФранциско було прийнято Декларацію про оцінювання наукових досліджень (San Francisco Declaration on Research Assessment) [22]. Вона закликає наукову громадськість відмовитися від використання імпакт-факторів для визначення результативності діяльності вчених і дослідницьких колективів, оскільки місія науки отримання нових знань, а не маніпулювання цифрами.

Незважаючи на деякі переваги експертної оцінки порівняно з наукометричними показниками, основним ii недоліком є суб'єктивність [12].

Проте зважене використання наукометричних показників у процесі оцінки наукового доробку співробітника, колективу або організації за кількістю публікацій у виданнях, що індексуються в міжнародних наукометричних базах, теоретично здатне позитивно вплинути на зростання їх наукової продуктивності [13, 21].

\section{Висновки}

1. Двадцять сім науковців ДУ «Інститут ендокринології та обміну речовин ім. В.П. Комісаренка НАМН України» створили особисті бібліометричні профілі на базі Google Scholar.

2. Кількість бібліографічних посилань у 3 науковців Інституту становить 6484, 4234 і 1304 одиниці, у 4 науковців - від 501 до 1000, у 7 науковців - від 101 до 500 і в 13 науковців - до 100.

3. Один науковець Інституту має індекс Гірша 43, 1 науковець - 34, 3 науковці - від 11 до 20, 5 науковців - від 6 до 10 і 17 науковців від 1 до 5.

4. У 19 науковців Інституту є публікації, які мають принаймні 10 бібліографічних посилань.

5. Останніми декількома роками рівень цитування публікацій науковців Інституту залишається стабільним.

\section{Список використаної літератури}

1. Савіна РВ, Волощук ОВ, Коркач ВС, Мельченко ЮВ. Наукометричний аналіз публікаційної активності фахівців ДУ «нститут громадського здоров'я ім. О.М. Марзєєва НАМН України» у виданнях, що входять до міжнародних баз даних. Довкілля та здоров'я. 2017;(2):68-71. (Savina RV, Voloshchuk OV, Korkach VS, Melchenko YuV. Scientometric analysis of publication activity of the specialists of SI «O.M. Marzeiev Institute for public health, National Academy of Medical Sciences of Ukraine» in the editions including in the international data bases. Environment\&Health. 2017;(2):68-71).

2. Костенко ЛЙ, Жабін ОI, Копанєва ЄО, Симоненко ТВ. Наукова періодика України та бібліометричні дослідження. НАН України, Нац. б-ка України ім. В.І. Вернадського, Київ, 2014;212c. (Kostenko LI, Zhabin OI, Kopanyeva EO, Symonenko TV. Scientific periodicals of Ukraine and bibliometric study. NAS of Ukraine, V.I. Vernadsky National Library of Ukraine, Kyiv, 2014;212 p.).

3. Hirsch JE. An index to quantify an individual's scientific research output. Proc Natl Acad Sci USA. 2005 Nov;102(46):16569-72.

4. Google Академія (Google Scholar).https://scholar.google.com.ua

5. Назаровець C. Наукометричні ресурси: у допомогу проведення та представлення наукових досліджень (Nazarovets S. Scientometric resources: to help for realization and present scientific research). ekmair. ukma.edu.ua/bitstream/handle/123456789/3015/scientometrics.pdf

6. Harzing.com. Research in International Management. Publish or perish. https://harzing.com/resources/publish-or-perish

7. Радченко AI. Про перший міжнародний семінар «Підготовка наукових журналів до індексування в аналітичних інформаційних системах SCIVERSE SCOPUS та PIHЦ SCIENCE INDEX: проблеми та рішення». Наука України у світовому інформаційному просторі. 2011;5:40-8. (Radchenko AI. About the first international seminar «Preparation of scientific journals for indexing in analytical information systems SCIVERSE SCOPUS and RISC SCIENCE INDEX: problems and solutions». Science of Ukraine in the world of information space. 2011;5:40-8).

8. Національна бібліотека України імені В.І. Вернадського. Бібліометрика української науки. Про проект. (V.I. Vernadsky national library of Ukraine. Bibliometrics of Ukrainian science. About the project). http://nbuviap.gov.ua/bpnu/index.php?page_ sites $=$ pro proect

9. Ranking Web of Universities. http://webometrics.info/en/node/194

10. Національна бібліотека України імені B.I. Вернадського. Бібліометрика української науки. Пошуковий запит: Інститут ендокринології та обміну речовин ім. В.П. Комісаренка (V.I. Vernadsky national library of Ukraine. Bibliometrics of Ukrainian science. Search request: V.P. Komisarenko Institute of Endocrinology and Metabolism). http:// nbuviap.gov.ua/bpnu/index.php?familie $=$ \&ustanova $=109 \&$ gorod $=0 \&$ vidomstvo $=\% \mathrm{C} 2 \% \mathrm{~F} 1 \% \mathrm{~B} 3 \&$ napryam $=0 \&$ napryam google $=0$.

11. Єрмаков СС. Проблеми та перспективи публікації статті в українському журналі, що входить до зарубіжної наукометричної бази. Вісник Чернігівського національного педагогічного університету. Серія: Педагогічні науки. Фізичне виховання та спорт. 2013;112(2):104-12. (Iermakov SS. Problems and prospects of Ukrainian publishing an article in a journal that is a foreign scientific metric base. Visnyk Chernihivs'koho natsional'noho pedahohichnoho universytetu. Seriya: Pedahohichni nauky. Fizychne vykhovannya ta sport. 2013;112(2):104-12).

12. Дзяк ГВ, Потоцкая ОЮ. Российский индекс научного цитирования как оптимальная наукометрическая база для анализа украинской научной периодики. Морфологія. 2013;VII(3):127-37. (Dzyak GV, Pototska OYu. Russian index of scientific citation as the optimal scientometric database for the integration of Ukrainian scientific periodicals). Morfolohiya. 2013;VII(3):127-37.

13. Назаровець С. Квартильний підхід до проблеми стимулювання росту наукової продуктивності в університетах. Бібліотечний форум: історія, теорія і практика. 2016;(24):10-2. (Nazarovets C. A quartile approach to the problem of stimulating the growth of scientific productivity in universities. Bibliotechnyy forum: istoriya, teoriya i praktyka. 2016;(24):10-2).

14. Назаровець С. Квартильний підхід до проблеми стимулювання публікаційної активності українських науковців (Nazarovets C. A quartile approach to the problem of stimulating the publishing activity of Ukrainian scientists). https://www.researchgate. 
net/publication/284283049_Kvartilnij_pidhid_do_problemi stimuluvanna_publikacijnoi_aktivnosti_ukrainskih__naukovciv

15. Рейтинги сайтів КПІ ім. Ігоря Сікорського. Реєстрація в Google Академіï. (Ratings of Igor Sikorsky Kyiv Polytechnic Institute sites. Registration in Google Academy). http://webometr.kpi.ua/ scholar-registration

16. Національна бібліотека України імені В.І. Вернадського. Бібліометрика української науки. Аналітика. Рейтинг відомств і установ за кількістю вчених, індекс Гірша яких $\geq 20$ (згідно наявних y Google Scholar бібліометричних портретів) (V.I. Vernadsky National Library of Ukraine. Bibliometrics of Ukrainian science. Analytics. The ranking of agencies and institutions by number of scientists, the Hirsch index of which is $\geq 20$ (according to bibliometric portraits available on Google Scholar)). http:// nbuviap.gov.ua/bpnu/index.php?page_sites=top_h_15\&ind $=20$

17. Національна бібліотека України імені В.І. Вернадського. Бібліометрика української науки. Аналітика. Рейтинг відомств і установ за кількістю вчених, індекс Гірша яких $\geq 30$ (згідно наявних y Google Scholar бібліометричних портретів) (V.I. Vernadsky National Library of Ukraine. Bibliometrics of Ukrainian science. Analytics. The ranking of agencies and institutions by number of scientists, the Hirsch index of which is $\geq 30$ (according to bibliometric portraits available on Google Scholar)). http:// nbuviap.gov.ua/bpnu/index.php?page_sites $=$ top_h_15\&ind $=30$

18. Національна бібліотека України імені В.І. Вернадського. Бібліометрика української науки. Аналітика. Рейтинг відомств і установ за кількістю вчених, індекс Гірша яких $\geq 40$ (згідно наявних y Google Scholar бібліометричних портретів) (V.I. Vernadsky National Library of Ukraine. Bibliometrics of Ukrainian science. Analytics. The ranking of agencies and institutions by number of scientists, the Hirsch index of which is $\geq 40$ (according to bibliometric portraits available on Google Scholar)). http:// nbuviap.gov.ua/bpnu/index.php?page sites $=$ top $\mathrm{h} \quad 15 \&$ ind $=40$

19. Національна бібліотека України імені B.I. Вернадського. Бібліометрика української науки. Аналітика. Рейтинг університетів і науково-дослідних інститутів (V.I. Vernadsky national library of Ukraine. Bibliometrics of Ukrainian science. Analytics. The rating of universities and research institutes). http://nbuviap. gov.ua/bpnu/index.php?page_sites=ustanovy

20. Національна бібліотека України імені В.І. Вернадського. Бібліометрика української науки. Аналітика. Рейтинг наукових колективів (V.I. Vernadsky National Library of Ukraine. Bibliometrics of Ukrainian science. Analytics. The rating of scientific collectives). http://nbuviap.gov.ua/bpnu/index.php?page sites=kollectivy

21. Hicks D, Wouters P, Waltman L, de Rijcke S, Rafols I. Bibliometrics: The Leiden Manifesto for research metrics. Nature. 2015 Apr;520(7548):429-31.

22. San Francisco Declaration on Research Assessment. https:// sfdora.org/read/

(Надійшла до редакції 19.04.2018 р.)

\section{Наукометрический анализ публикационной активности ученых ГУ «Институт эндокринологии и обмена веществ им. В.П. Комиссаренко НАМН Украины» по данным наукометрической базы данных Google Scholar}

\section{Н.Д. Тронько, И.П. Пастер \\ ГУ «Институт эндокринологии и обмена веществ имени \\ В.П. Комиссаренко НАМН Украины»}

Резюме. Проведен наукометрический анализ публикационной активности ученых ГУ «Институт эндокринологии и обмена ве- ществ им. В.П. Комиссаренко НАМН Украины» по данным наукометрической базы данных Google Scholar. Личные библиометрические профили создали 27 ученых. Количество библиографических ссылок у 3 ученых составляет 6484, 4234 и 1304 единицы, у 4 — от 501 до 1000, у 7 - от 101 до 500 и у 13 - до 100. Один ученый имеет индекс Хирша 43, 1 - 34, 3 - от 11 до 20, 5 - от 6 до 10 и 17 от 1 до 5. У 19 ученых есть публикации, которые имеют по крайней мере 10 библиографических ссылок. В последние несколько лет уровень цитирования публикаций ученых остается стабильным.

Ключевые слова: ГУ «Институт эндокринологии и обмена веществ им. В.П. Комиссаренко НАМН Украины», публикации ученых, наукометрическая база данных Google Scholar, наукометрический анализ.

\section{A scientometric analysis of the publication activity of scientists in State Institution «V.P. Komisarenko Institute of Endocrinology and Metabolism, Natl. Acad. Med. Sci. of Ukraine» based on data from a scientometric database of Google Scholar}

\author{
M.D. Tron'ko, I.P. Pasteur \\ State Institution «V.P. Komisarenko Institute of Endocrinology \\ and Metabolism, Natl. Acad. Med. Sci. of Ukraine»
}

\begin{abstract}
The aim of the study was to carry out a scientometric analysis of the publication activity of scientists in SI «V.P. Komisarenko Institute of Endocrinology and Metabolism, Natl. Acad. Med. Sci. of Ukraine» based on data from the scientometric database of Google Scholar. Material and methods. Method of study was the scientometric analysis of scientific publications according to the data of Google Scholar scientometric database. All the personal biometric profiles of Institute scientists on the platform of Google Scholar became an object of study. A number of bibliographic references of all the publications, h-index and i10 index for all period and from 2013 year were the subject of study. Results. Personal bibliographic profiles were created by 27 scientists. The number of bibliographic references in 3 scientists consists of 6484,4234 and 1301 units, in 4 scientists - from 501 to 1000, in 7 scientists from 101 to 500, and in 13 scientists - up to 100. The Hirsch index in one scientist is 43 , in one another - 34, in 3 scientists - from 11 to 20, in 5 scientists - from 6 to 10 , and in 17 scientists from 1 to 5 . The 19 scientists have publications at least with 10 bibliographic references. Conclusion. In the Institute the citation level of the scientific publications remains stable in the last few years.
\end{abstract}

Keywords: V.P. Komisarenko Institute of Endocrinology and Metabolism, Natl. Acad. Med. Sci. of Ukraine, publications of scientists, Google Scholar scientometric database, scientometric analysis. 